\title{
Improving High-Level Thinking Skills by Development of Learning PBL Approach on the Learning Mathematics for Senior High School Students
}

\author{
Edy Surya ${ }^{1} \&$ Edi Syahputra ${ }^{1}$ \\ ${ }^{1}$ Mathematics Education FMIPA Unimed Medan, North Sumatera, Indonesia \\ Correspondence: Edy Surya, Jl. Willem Iskandar Psr. V Medan, 20221, Indonesia. E-mail: \\ edy_surya71@yahoo.com
}

Received: August 1, 2016

Accepted: April 5, $2017 \quad$ Online Published: July 29, 2017

doi:10.5539/ies.v10n8p12

URL: https://doi.org/10.5539/ies.v10n8p12

\begin{abstract}
This study aims to improve the ability of high-level thinking by developing learning models based on problems in senior high school students. The type study is research development. The subject of dissemination consists in 3 distric/city in North Sumatera, namely: SMK Negeri 6 Medan, MAN Deli Serdang Distric and SMA Yapim Taruna Langkat Distric, SMA YPK Medan City. Instrument of Collecting data used are observation guidelines, questionnaires, interview guides, students mathematics text books for $11^{\text {th }}$ grade in Senior high school, Teacher's guide book, instrument of pre-test and post-test. Development of model is adopted from Thiagarajan's model and Semmel \& Semmel's model. This study has compiled teaching materials in the form of textbooks for students' and teacher's guide book that includes the structured steps of solving mathematical problems based on problem solving which can construct high-level thinking. Results of dissemination showed a significant improvement of students' problem solving ability in three districts/cities in North Sumatra at four schools.
\end{abstract}

Keywords: learning model, problem-based learning, high-level thinking

\section{Introduction}

Failures in school mathematics are largely associated with teaching traditions that are Not in accordance with the way most students learn (National Research Council [NRC], 1989). In effective teaching and learning of mathematics due to the traditional method (TM) of teaching that has dominated the classroom worldwide has been associated with the dismal performances of students in mathematics (Van de Walt \& Maree, 2007; Dossey, McCrone, Giordano, \& Weir, 2002). Traditional methods of teaching mathematics have been found to be very defective and full of many inadequacies that do not allow students to actively construct their own mathematical knowledge (Dubinsky, 1991; Mji, 2003). It has adversely affected effective learning at the different levels of education. Education is facing many challenges in terms of student performance particularly in the physical sciences (DoE, 2006) and this is as result of the introduction of new topics into the curriculum which the teachers perceive as difficult to teach (DoE, 2006; Turmudi, 2010; Fatade, et al, 2013). Recommended structure teaching of mathematical concepts and skills around problems to be solved (Checkly, 1997; Wood \& Sellars, 1996; Wood \& Sellars, 1997) Encourage students to work cooperatively with others (D. Johnson \& R. Johnson, 1975; Davidson, 1990)

The need to set standards for higher order thinking skills has been documented throughout the 1980s and 1990s. In the 1980s, documentation came from the National Assessment for Educational Progress (NAEP); the National Commission on Excellence in Education in A Nation at Risk (1983); Goodlad's A Place Called School (1984), which focused on social studies and science; the 1985 Commission on Reading report called Becoming a Nation of Readers (Anderson, 1985); and the 1986 Carnegie Forum on Education and the Economy's Task Force on Teaching (Carnegie Corporation, 1986).

Students' interaction in ways that both support and challenge one another's strategic thinking (Artzt, Armour-Thomas, \& Curcio, 2008). Observation result showed that Learning Model of Mathematics in Senior High School this time is not referred to specific learning theory yet. At the Learning process in the class, students were given ordinary problems that can be solved with simple analysis and mechanistic solution. Almost all of the learning process of mathematics in school beginning with shares of definition, formula, example, and ends with 
exercises. Occasionally be found, the proof of mathematical problems are solved by using a figure or a simple sketch. This condition was notable to improve the creativity and critical thinking of students.

Moreover in learning at the class, Students are not accustomed to thinking axiomatic deductive, also students are not supported by their mathematics textbooks that are used. Most of the learning process of mathematics in SMA, lead students to memorize, solving mathematical problems ordinarily and a simple analyze inductively by following existing examples. Ironically, Teacher teach students by following monotonous method that are given in mathematics text books without considering student's cognitive improvement level. Whereas, learning mathematics requires innovation and creativity of teachers and students. Due to it, Sumarmo (2005) state that student's problem solving ability is still low.This notion of loss of control associated with a lack of confidence to allow students to explore and investigate freely is an important issue in being prepared to adopt problemsolving approaches, particularly if problem solving is considered to be a process of inquiry (Smith, 2000; Surya, 2013; Nasution, Surya \& Syahputra, 2015). In addition, a teacher's competence in relation to problem solving was considered to be a real issue for one respondent who suggested

In the Curriculum 2013, the learning is using scientific method, multi-strategy, multimedia, adequate learning source and technology, and utilizing the environment as a learning resource. Learning Model that used is problem based learning. This model is appropriate to improve student's mathematical problem solving ability. In the learning process, student's activity is started with observation, then asking questions, trying, making network, and analyzing. Therefore now and future, we need learning model that should be able to improve student's mathematical problem solving ability in Secondary High School.

\subsection{Problem-Based Learning}

Problem-based learning began at McMaster University Medical School over 25 years ago. It has since been implemented in various undergraduate and graduate programs around the world. Additionally, elementary and secondary schools have adopted PBL. The PBL approach is now being used in few community colleges also. Problem-Based Learning (PBL) describes a learning environment where problems drive the learning. That is, learning begins with a problem to be solved, and the problem is posed is such a way that students need to gain new knowledge before they can solve the problem. Rather than seeking a single correct answer, students interpret the problem, gather needed information, identify possible solutions, evaluate options, and present conclusions. Proponents of mathematical problem solving insist that students become good problem solvers by learning mathematical knowledge heuristically. Students' successful experiences in managing their own knowledge also help them solve mathematical problems well (Shoenfeld, 1985; Boaler, 1998). Problem-based learning is a classroom strategy that organizes mathematics instruction around problem solving activities and affords students more opportunities to think critically, present their own creative ideas, and communicate with peers mathematically (Krulik \& Rudnick, 1999; Lewellen \& Mikusa, 1999; Erickson, 1999; Carpenter et al., 1993; Hiebert et al., 1997; Padmavathy, \& Mareesh, 2013).

Problem-based curricula provide students with guided experience in learning through solving complex, real-world problems. PBL was designed with several important goals (Barrows and Kelson, 1995). It is designed to help students 1) construct an extensive and flexible knowledge base; 2) develop effective problem-solving skills; 3) develop self-directed, lifelong learning skills; 4) become effective collaborators; and 5) become intrinsically motivated to learn. (Hmelo-Silver, 2002)

\subsection{Higher-Order Thinking Skills}

The challenge of defining "thinking skills, reasoning, critical thought, and problem solving" has been referred to as a conceptual swamp in a study by Cuban (as cited in Lewis \& Smith, 1993, p. 1), and as a "century old problem" for which "there is no well-established taxonomy or typology" (Haladyna, 1997, p. 32). In addition, explanations of how learning occurs have been viewed as inadequate, with no single theory adequately explaining "how all learning takes place" (Crowl, Kaminsky, \& Podell, 1997, p. 23). Several factors may account for these views about thinking and learning. First, different types of learning require different teaching strategies Cno single method works for all learning, although specific strategies work for specific types. Second, intelligence is no longer seen as an unchanging general ability but rather a kaleidoscope of abilities that can be affected by a variety of factors, including teaching strategies. Third, the understanding of the thinking process has shifted to a multidimensional view-much more like a complex network of interactive capabilities rather than a linear, hierarchical, or spiral process. Fourth, the research over the last two decades has focused on more specialized topics such as insight, wait time for problem solving, visual imagery and metaphors, and schemata. Despite the challenges related to defining higher order thinking, educators, administrators, and evaluators in Florida and across the nation have expressed agreement about the value of teaching it (Carrol, 1989; Cotton, 
1997; Ennis, 1993; Glaser \& Resnick, 1991; Haladyna, 1997; Howe \& Warren, 1989; Huberty \& Davis, 1998; Kauchak \& Eggen, 1998; Kerka, 1986; King, 1997; Marzano, Brandt, Hughes, Jones, Presseisen, Rankin, \& Suhor, 1988; Patrick, 1986; Siowck-Lee, 1995; Young, 1997). There is a renewed awareness that, although information and memory provide "a refrigerator in which to store a stock of meanings for future use," it is Higher Order Thinking Skills

Page 8 judgment that "selects and adopts the one to be used in an emergency . .." (Dewey, 1933, p. 125). Complex real-life problems often demand complex solutions, which are obtained through higher level thinking processes. Teaching higher order thinking, then, provides students with relevant life skills and offers them an added benefit of helping them improve their content knowledge, lower order thinking, and self-esteem (DeVries \& Kohlberg, 1987; McDavitt, 1993; Son \& VanSickle, 1993).

\section{Method}

This Study is kind of the development research. The stages of learning model follow the procedure of Thiagarajan et al. (1974). According to Thiagarajan et al. (1974), Development model that used is refers to four D-Model. Where consist of 4 steps namelydefine, design, develop, and disseminate. Results of development are described as follows:

Table 1. Stage of definition and make the identification purpose of learning

\begin{tabular}{ll}
\hline Stage 1 & Reseacher Activity \\
\hline Step 1 & Analysis Curriculum 2013 and SKL Secondary High School (SMA/MA) \\
Step 2 & Theory-Analysis of Problem-Based Learning \\
Step 3 & Characteristic Analysis, Background, and Development of student's cognitive \\
Step 4 & Selection of learning media, Selection of Format \\
Step 5 & *-Material Analysis *-Concept Analysis *- Assignment Analysis \\
Step 6 & Identification Purpose of Learning Mathematics in SMA/MA \\
\hline
\end{tabular}

The purpose of this stage are set and defining learning activity by conducting analysis purpose and material limitations. In the stage of Define, will be desribed five activities that must be done namely: ujung-depan analysis (analysis Mathematics curriculum of SMA), Students analysis, concept and material analysis, assigment and formulation of learning purpose. Stage of define are described as follows:

\section{a. Ujung-Depan Analysis}

Purpose of this analysis is to analyze the basic problem that encountered in the development of learning model. Several things to note in Ujung-Depan Analysis are curriculum of 2013 and learning theory of Problem-Based Learning.

\section{b. Students Analysis}

This analysis is done by observing the characteristics, ability and initial knowledge of students both as individuals and groups. In this analysis, it also can be seen the student characteristic in accordance with the design and development of teaching material. These characteristics consist of ability and background, experience, attitudes toward learning topics, media selection, the selection of format, language used and the cognitive development of students.

\section{c. Concept and material Analysis}

This analysis intended to identify, specify, compile systematically relevant material. The material will be developed then tested and taught by problem-based learning based on the ujung-depan analysis.

\section{d. Assignment Analysis}

This analysis intended to identify skills of students that are needed in mathematics curriculum in SMA based oncurriculum 2013 and analyze it to a sub frame of skill.

\section{e. Formulation of learning purpose}

This analysis intended to convert the purpose of the assignment analysis and concepts analysis into specific learning objectives that expressed by the behavior of students in learning. 
Table 2. Stage of identification of indicator, determining the textbook material, and initial design

\begin{tabular}{ll}
\hline Stage 2 & Reseacher Activity \\
\hline Step 1 & Identification Indicator the purpose of learning and basic competence \\
Step 2 & Determining the mathematics textbook material Problem based learning of 11th grade in SMA/MA \\
Step 3 & Initial design of mathematics textbook of 11th grade in SMA/MA \\
Step 4 & Arranging of mathematics textbook-manuscript of 11th grade in SMA/MA \\
\hline
\end{tabular}

This stage are purposed to design the learning model and supporting instrument that consistof Students mathematics textbooks of 11th grade in SMA/MA based on Problem Based Learning and Teacher's guide book. Result of design is called Draft-1. The activity of this stage consist ofidentify indicator of learning objectives and basic competence, define Problem based learning as the basis of Learning model of mathematics, initial design of mathematics book-manuscript of 11 th grade in SMA/MA, and drafting the mathematics book-manuscript of 11th grade in SMA/MA.

Table 3. Stage of Revision, Revision-I, Trials, and Revision-II

\begin{tabular}{ll}
\hline Stage 3 & Reseacher Activity \\
\hline Step 1 & mathematics textbook-manuscript of 11th grade in SMA/MA and Teacher's guide book \\
Step 2 & Revision by expert from Mathematics Education and Indonesia language \\
Step 3 & $\begin{array}{l}\text { Revision-I } \\
\text { Substantial of content, language and Format }\end{array}$ \\
Step 4 & Limited Trials \\
Step 5 & $\begin{array}{l}\text { Revision-II } \\
\text { Substantial of content, language and Format }\end{array}$ \\
\hline
\end{tabular}

At this stage there are four activities, namely:

\section{a. Validation}

Stage of developing, started with validation by an expert then validation is conducted to the instrument of students textbook and teacher's guide book where it is designed in stage 2 (Draft I). Validation is conducted to content teaching material, language and format that is used. Validation are conducted by an expert of mathematics in Senior high school, expert of indonesia literature, and expert of learning theory of mathematics for school. Aspects that are observed namely: whether steps scientific approach (observe, ask, try, associate and communicate) has been qualified on students textbooks and teacher's guide book, whether subject matter is arranged in a hierarchical (ordered according pre conditions material), whether sentence in the students textbook and teachers guide book is easy to understand, whether sentence in the text is not ambiguous, whether display and content of the text book interesting, whether the questions varied, whether the questions are presented contextually, whether sentences in questions are not ambiguous.

\section{b. Revise}

After experts provide the results of the assessment, Team revised the tools and instruments. Suggestions of experts are used to complete the mathematics book-manuscript of $11^{\text {th }}$ grade in SMA/MA and teacher's guide book. The result of revised students book-manuscript and teacher's guide book at this stage is called revision-I.

\section{c. Trials}

After doing revision-1 for students book-manuscript, teacher's guide book, and other instruments, The next activity doing trials on a limited basis. The trial is called as limited because of its dependence on the schedule of learning materials in schools were tested. So not all the material in students book-manuscript can be tested.Trials were conducted in four schools in 3 city/district in North Sumatera namely; SMA Swasta Yapim Taruna Stabat Langkat district, SMK Negeri 6 Medan City, SMA YPK Medan City, and MAN Lubuk Pakam Deli Serdang District. The Aspect that was observed in this trials is whether sentences in student textbook are easy to understand, whether the sentence in the book does not have a double meaning, whether display and content of the book interesting, whether the questions in student textbook varies, and whether the question in student textbook is easy to understand. In addition, the processes and activities of the students also studied during the implementation of the trial took place. Aspects are observed consist of; whether students are actively observing the learning material in each study group, whether students are actively asked in a group study, whether students 
are actively trying to solve the problems given in the textbook, whether students can connect information obtained from a given problem according to their way, whether students communicate the results of his thoughts with his friend whether students doing activities that are not related to ongoing learning, whether teachers arrange study groups at the beginning of learning, whether teachers give scaffolding, whether teachers give appropriate answers students questions, whether teachers instruct students to observe, ask, try, associate and communicate.

\section{d. 2nd Revise}

After Trials has been done, team revisions to the content of students book-manuscript and teacher's guide book and other istruments. The Revisions are based on the invention of a trial result. Refinement has been done on formatting, grammar of Indonesia Language in a sentence (so contains number response) and graphs or pictures (so has a meaning that can be understood by students).

Table 4. Stage of dissemination (validation trials) of learning model

\begin{tabular}{|c|c|}
\hline Stage 4 & Reseacher Activity \\
\hline Step 1 & $\begin{array}{l}\text { Validation trials in SMA Swasta Yapim Taruna Stabat Langkat District, SMK Negeri } 6 \text { Medan, SMA YPK Medan, and MAN } \\
\text { Lubuk Pakam, Deli Serdang District }\end{array}$ \\
\hline Step 2 & $\begin{array}{l}\text { Instrument of learning model consists of mathematics textbook-manuscript of 11th grade in SMA/MA and Teacher's guide } \\
\text { book etc. }\end{array}$ \\
\hline
\end{tabular}

In this stage, there is only one activity. That is Validation trials. For the process of learning in the class, instruments that used are textbook-manuscript of $11^{\text {th }}$ grade in SMA/MA, Teacher's guide book and other instruments. While, Learning model that implemented is based on problem solving that used textbook-manuscript of $11^{\text {th }}$ grade in SMA/MA and Teacher's guide book. This Activity was conducted in SMA Privat Yapim Taruna Stabat Langkat District, SMK Negeri 6 Medan City, SMA YPK Medan, and MAN Lubuk Pakam Deli Serdang District.

Figure 1 shows the fishbone diagram that illustrates the development process of learning model and achievement targets.

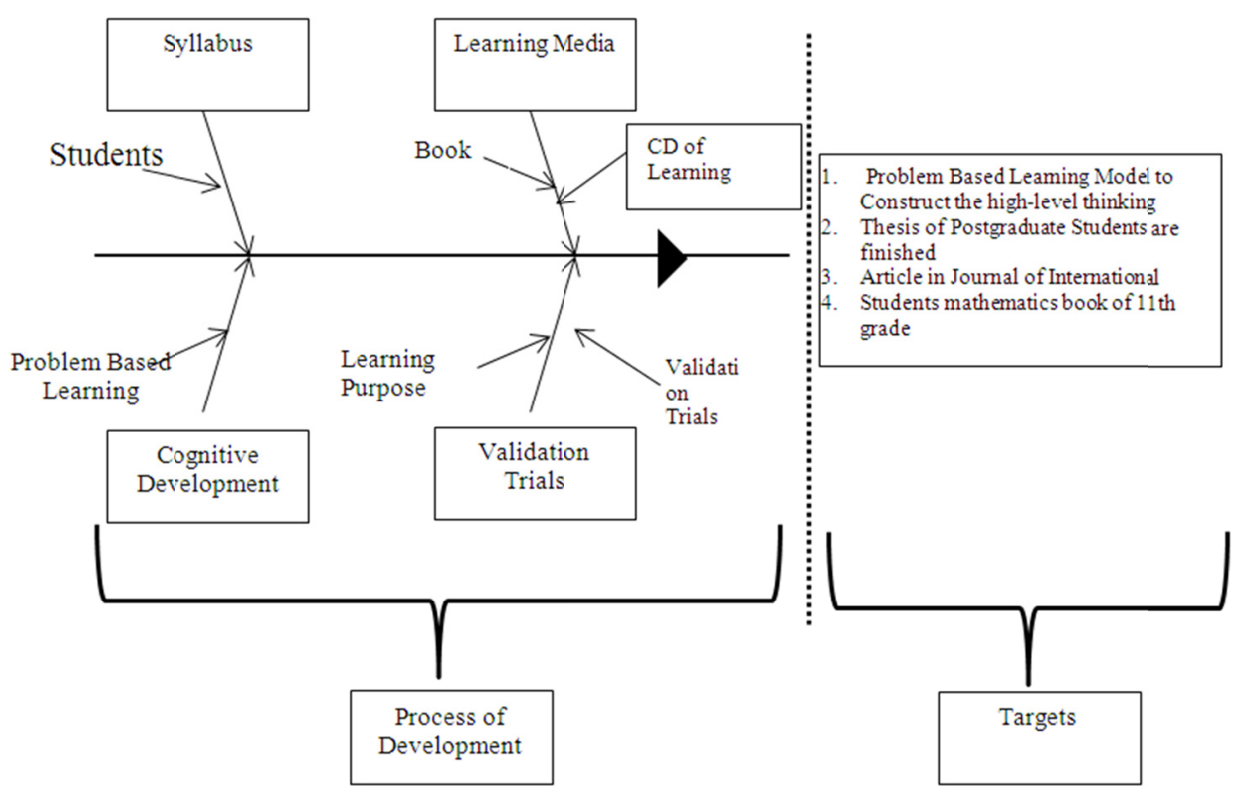

Figure 1. Fishbone diagram

\section{Result and Discussion}

\subsection{Result of Study}

Results of this research consist of learning models and supporting instruments which are; one package of 
mathematics learning instrument of $11^{\text {th }}$ grade in SMA/MA, questionnaires, observation guidelines, interview guides, students mathematics textbook of $11^{\text {th }}$ grade in SMA/MA, teacher's guide book, and instrument of pre-test and post-test.

Based on trials on four schools in three city/district obtained the following results: as 33 from 37 students (89\%) of $11^{\text {th }}$ grade students in SMK Negeri 6 Medan said that the sentence in the book is easy to understand.25 students (68\%) said that the sentence in the book does not have a double meaning. as 34 students (92\%) said that the display contents of the book interesting, and as 31 students (84\%) said that the problems in the book vary. As more important, there are 22 students $(59 \%)$ said that the sentence in the problem is easy to understand. In SMA Swasta YAPIM Stabat, 25 from 41 students $(61 \%)$ of $11^{\text {th }}$ grade said that the sentence in the book is easy to understand. As 27 students (66\%) said that the sentence in the book does not have a double meaning. As 35 students (85\%) said that the display contents of the book interesting and as 39 students $(95 \%)$ said that the problems in the book vary. While as 23 students $(56 \%)$ said that the sentence in the problem is easy to understand.

In SMA YPK Medan as 32 from 37 students $(86 \%)$ of $11^{\text {th }}$ grade said that the sentence in the book is easy to understand. As 25 students (68\%) said that the sentence in the book does not have a double meaning. As 21 students (57\%) said that the display contents of the book interesting and as 34 students (92\%) said that the problems in the book vary. While as 27 students (73\%) said that the sentence in the problem is easy to understand. In MAN Lubuk Pakam there are 31 from 32 students (97\%) of $11^{\text {th }}$ grade said that the sentence in the book is easy to understand. As 30 students (94\%) said that the sentence in the book does not have a double meaning. As 22 students (69\%) said that the display contents of the book interesting, as 26 students $(81 \%)$ said that the problems in the book vary. As 29 students (91\%) said that the sentence in the problem is easy to understand.

In addition, there is a significant improvement of student's mathematical problem-solving ability. It is proven by the differences in an average of normalized gain between the result of learning in Cycle-I and Cycle-II. The students average of N-Gain in Cycle-I is 0,312 and in Cycle-II is 0,441. After trials with t-test there is the significant improvement from both of result.

\subsection{Discussion}

Piaget observed the activities of children and later developed tasks to test developmental growth in the children. From this observation came Piaget's idea that cognitive development occurs in stages and that this development progresses through active interaction with the environment and the development of "schemes". This "active interaction" is one of the major components of PBL. Piaget suggests that these schemes are built through self-directed, active interaction and when a new situation, or problem, arises we try to apply our scheme to a new situation (Qayumi, 2001). Lev Vygotsky, a social constructivist, suggested the idea of the zone of proximal development (ZPD) which is the difference between what a learner can do on their own and what they can achieve with teacher help or scaffolding. He suggests that learning is achieved by imitating and modeling more experienced learners and that social context is required for learning and development (Gebhard, 2008). He further suggests that learning and development require authentic tasks to achieve the learner's full potential. Authentic activities must be relevant to the learner, in other words a "real world" activity. Lastly, Vygotsky suggests that learning is a personal process and in coordination with real-world activities motivation of the student is increased as disinterest decreases (Gebhard, 2008). These factors can be seen in the underlying principles of PBL. Real-world, relevant, authentic situational learning is of core importance to PBL in the medical classroom and the role of the tutor fulfills the need for experienced scaffolding and imitation while peers provide the social learning aspect (Pagander and Read, 2014).

Padmavathy and Mareesh (2013) in the result of the study revealed that problem-based learning had effect in teaching mathematics and improve students understanding, ability to use concepts in real life. From the test results that have been conducted, the learning activity is going well as expected. Students are actively observing learning material and asking in their study group. The students are actively trying solve the problem that is given. Student can connect the information that they got from the problem given. Students are actively communicating their opinion to their study group. Significantly, we cannot see the students do things outside of learning. In the other side, research shows that teachers always arrange study group to form of 3 until 4 students in the beginning of learning. Teacher gives scaffolding, gives the correct answer based on student's questions and teacher always direct students to observe, ask, try, associate, and communicate the learning material with their a each study group. After that, every group must present their work in front of the class. This phenomenon is consistent with results of research Muncarno (2001) which argues that learning using steps of problem solving can foster 
earnestness of students during the learning takes place, involvement in the learning process makes the class seem alive and excited to answer questions and solve the problems given by the teacher. In addition, research that done by Suwangsih (2004) informs that mathematics problem-based learning using model Group Investigation Technique can improve student's learning outcome. Suwangsih's opinion is consistent with the result of this study. In quantitatively there is a significant improvement in student's mathematical problem-solving ability from learning Cycle-I to next Cycle.

\section{Conclusion}

Concretely learning model can be implemented to improve students' high-level thinking ability in solving mathematical problem. In addition, this study creates the teaching material in the form of mathematics textbook of $11^{\text {th }}$ grade in Senior High School students and teacher's guide book where is included the structured steps of mathematics problem solving to construct the high-level thinking. The result of trial shows a significant improvement of student mathematical problem solving ability.

\section{Suggestion}

Based on these results, the researchers recommended that the learning model and the entire instrument are applied in the mathematics learning for $11^{\text {th }}$ grade in Senior High School students. The main instruments in this model are students textbook and teacher's guidebook. Thus, students get used to construct high-level thinking in mathematics learning.

\section{Acknowledgments}

This study is part of the Competitive Grant Research Project. Thank you for the Ministry of Research, Technology and Higher Education. We are grateful to the Minister who has been supporting this research. We also thank the Rector of the State University of Medan who has supported this research. Thanks also to colleagues in the Department of Mathematics who have always supported us, and also, math teachers and experts involved in the project in the school.

\section{References}

Anderson, R. C. et al. (1985). Becoming a nation of readers: The report on the commission on reading. Washington, DC: National Institute of Education.

Artzt, A. F., Armour-Thomas, E., \& Curcio, F. R. (2008). Becoming a reflective mathematics teacher. New York: Lawrence Erlbaum Associates.

Barrows, H. S., \& Kelson, A. C. (1995). Problem based learning in secondary education and the problem based learning institute. Springfield, IL.

Boaler, J. (1998). Open and closed mathematics: student experiences and understandings. Journal for Research on Mathematics Education, 29(1). 41-62. https://doi.org/10.2307/749717

Carnegie Forum on Education and the Economy's Task Force on Teaching as a Profession. (1986). A nation prepared: Teachers for the 21st century. New York: Carnegie Corporation.

Carpenter, T., Ansell, E., Franke, M., Fennema, E., \& Weisbeck, L. (1993). Models of problem solving: A study of kindergarten children's problem solving processes. Journal for Research in Mathematics Education, 24(5), 428-441. https://doi.org/10.2307/749152

Carrol, T. M. (1989). Critical thinking: Promoting it in the classroom. ERIC Digest [On-line]. Retrieved from http://ericae2.educ.cua.edu/edo/ed306554.htm

Checkley, K. (1997). The First Seven and the Eighth: A Conversation with Howard Gardner. Association for Supervision and Curriculum Development. Retrieved from http://www.ascd.org/publications/ed_lead/199709/checkley.html

Crowl, T. K., Kaminsky, S., \& Podell, D. M. (1997). Educational psychology: Windows on teaching. Madison, WI: Brown and Benchmark.

Davidson, N. (Ed.). (1990). Cooperative learning in mathematics: A handbook for teachers. Menlo Park, CA: Addison-Wesley.

Department of Education (DoE). (2006). Policy handbook for educators Pretoria: Government Printer.

DeVries, R., \& Kohlberg, L. (1987). Programs of early education: The constructivist view. New York: Longman.

Dewey, J. (1933). How we think: A restatement of the relation of reflective thinking to the educative process. Boston: D. C. Heath and Company. 
Dossey, J. A., McCrone, S., Giordano, F. R., \& Weir, M. (2002). Mathematics Methods and Modeling for Today's Mathematics Classroom: A Contemporary approach to teaching Grades 7-12. Brooks/Cole Thompson Learning Academic Resource Centre (p. 34).

Dubinsky, E. (1991). 'Reflective Abstraction' in Advanced Mathematical Thinking. In D. Tall (Ed.), Advanced Mathematical Thinking (pp. 95-102). Dordrecht The Netherlands: Kluwer Academic.

Ennis, R. H. (1993). Critical thinking assessment. Theory into Practice, 32(3), 179-186. https://doi.org/10.1080/00405849309543594

Erickson, D. K. (1999). A problem-based approach to mathematics instruction. Mathematics Teacher, 92(6), 516-521

Fatade, A. O., Mogari, D, Adelaja, A., \& Arigbabu. (2013). Effect of Problem-Based Learning on Senior Secondary School Students' Achievements in Further Mathematics. Acta Didactica Napocensia, 6(3), 27-43.

Gebhard, S. (2008). Vygotsky and the Zone of Proximal Development. In L. A. Tomei (Ed.), Encyclopedia of Information Technology Curriculum Integration (pp. 948-950). Robert Morris University. https://doi.org/10.4018/978-1-59904-881-9.ch148

Glaser, R., \& Resnick, L. (1991). National research center on student learning (ERIC Document Reproduction Service No. ED 338 704).

Goodlad, J. I. (1984). A place called school. New York: McGraw Hill.

Haladyna, T. M. (1997). Writing test items to evaluate higher order thinking. Boston: Allyn and Bacon.

Hiebert, J., Carpenter, T. P., Fennema, E., Fuson, K., Human, P., Murray, H., Olivier, A., \& Wearne, D. (1997). Making mathematics problematic: A rejoinder to Prawat and Smith. Educational Researcher, 26(2), 24-26. https://doi.org/10.2307/1176035

Hmelo-Silver, C. E. (2002). Collaborative ways of knowing: Issues in facilitation. In G. Stahl (Ed.), Proceedings of CSCL 2002, Erlbaum, Hillsdale, NJ (pp. 199-208). https://doi.org/10.3115/1658616.1658645

Howe, R. W., \& Warren, C. R. (1989). Teaching critical thinking through environmental education. ERIC/SMEAC Environmental Digest No. 2. Retrieved from http://ericae.net/db/digs/ed324193.htm

Johnson, D., \& Johnson, R. (1975). Learning together and alone: Cooperation, competition, and individualization. Englewood Cliffs, NJ: Prentice Hall.

Kauchak, D. P., \& Eggen, P. D. (1998). Learning and teaching: Research-based methods (3rd ed.). Boston: Allyn and Bacon.

Kerka, S. (1986). Higher order thinking skills in vocational education. ERIC Digest No. 127. Retrieved from http://ericae.net/db/digs/ed350487.htm

King, F. J., Rohani, F., \& Goodson, L. (1997). Statewide assessment of listening and verbal communication skills, information literacy skills, and problem-solving skills. Tallahassee: Florida State University.

Krulik, S., \& Rudnick, J. A. (1999), Innovative tasks to improve critical- and creative-thinking skills. In I. V. Stiff (Ed.), Developing mathematical reasoning in grades K-12 (pp.138-145). Reston. VA: National Council of Teachers of Mathematics.

Lewellen, H., \& Mikusa, M. G. (1999). Now here is that authority on mathematics reform, Dr. Constructivist! The Mathematics Teacher, 92(2), 158-163.

Lewis, A., \& Smith, D. (1993). Defining higher order thinking. Theory into Practice, 32(3), 131-137. https://doi.org/10.1080/00405849309543588

Marzano, R. J., Brandt, R. S., Hughes, C. S., Jones, B. F., Presseisen, C. S., Rankin, S. C., \& Suhor, C. (1988). Dimensions of thinking: A framework for curriculum and instruction. Alexandria, VA: Association for Supervision and Curriculum Development.

McDavitt, D. S. (1993). Teaching for understanding: Attaining higher order learning and increased achievement through experiential instruction (ERIC Document Reproduction Service No. ED 374 093).

Mji, A. (2003). A three-year perspective on conceptions of and orientations to learning mathematics of prospective teachers and first year university students International Journal of Mathematical Education in Science and Technology, 34(5), 687-698. https://doi.org/10.1080/0020739031000148949 
Muncarno. (2001). Langkah-Langkah Pemecahan Masalah dalam Soal Cerita untuk Meningkatkan Prestasi Belajar Matematika Siswa Kelas VI SD. Bandung: Tesis PPS-UPI Bandung.

Nasution, P. R., Surya, E. \& Syahputra, E. (2015). Perbedaan Peningkatan Kemampuan Berpikir Kreatif Matematis dan Kemandirian Belajar Siswa Pada Pembelajaran Berbasis Masalah dan Pembelajaran Konvensional di SMPN 4 Padangsidimpuan. Paradikma Jurnal Pendidikan Matematika, 8(3).

National Commission on Excellence in Education. (1983). A Nation at Risk. Washington, DC: Author

National Research Council. (1989). Everybody counts: A report to the nation on the future of mathematics education. Washington, D.C.: National Academy Press.

Padmavathy, R. D., \& Mareesh, K. (2013). Effectiveness of Problem Based Learning in Mathematics. International Multidisciplinary e-Journal, II(I), 45-51.

Pagander, L., \& Read, J. (2014). Is Problem-Based Learning (PBL) An Effective Teaching Method? A Study Based on Existing Research. Linköpings universitet Lärarprogrammet.

Patrick, J. H. (1986). Critical thinking in the social studies. ERIC Digest No. 30. Retrieved from http://ericae.net/db/digs/ed272432.htm

Qayumi, S. (2001). Piaget and His Role in Problem Based Learning. Journal of Investigative Surgery, 14, 63-65. https://doi.org/10.1080/08941930152024165

Schoenfeld, A. H. (1985). Mathematical problem solving. New York: Academic Press.

Siowck-Lee, G. (1995). Multimedia environmental education courseware for promoting cooperative learning and higher-order thinking skills. Paper presented at the National Curriculum Seminar, Port Dickson, Malaysia.

Smith, M. S. (2000). Balancing old and new: An experienced middle school teacher's learning in a context of mathematics instructional reform. Elementary School Journal, 100(4), 351-375. https://doi.org/10.1086/499646

Son, B., \& Van Sickle, R. L. (1993). Problem-solving instruction and students' acquisition, retention and structuring of economics knowledge (ERIC Document Reproduction Service No. ED 366 627).

Sumarmo, U. et al. (2005). Pengembangan Berpikir Matematik Tingkat Tinggi Siswa SLTP dan SMU serta Mahasiswa Strata Satu (S1) Melalui Berbagai pendekatan Pembelajaran. Laporan Hibah Penelitian Pascasarjana. Tahun Ketiga, tidak diterbitkan.

Surya, E. (2013). Analisis Pemetaan dan Pengembangan Model Pembelajaran Matematika SMA di Kabupaten Tapteng dan Kota Sibolga Sumatera Utara. Jurnal Pendidikan Matematika PARADIKMA, 6(1), 76-89.

Suwangsih, E. (2004). Peningkatan Keterampilan Pemecahan Masalah Matematika Siswa Sekolah Dasar melalui Pembelajaran Kooperatif. Bandung: Tesis PPS-UPI Bandung.

Thiagarajan, S. et al. (1974). Instructional Development for Training Teachers of Exceptional Children. A Source Book. Blomington: Central for Innovation on Teaching The Handicapped.

Turmudi. (2010). Peningkatan Pembelajaran Matematika di Kelas dengan Skaffolding (Sebuah Kasus di Kelas Akselerasi SMPN 3 Malang). Prosiding Seminar Nasional Statistika Universitas Padjadjaran, 13 November 2010.

Van de Walle, J. A. (2007). Elementary and Middle School Mathematics-Teaching Developmentally (pp. 1-70). Pearson Education Inc; Boston.

Young, A. C. (1997). Higher-order learning and thinking: What is it and how is it taught? Educational Technology, 37, 38-41.

\section{Copyrights}

Copyright for this article is retained by the author(s), with first publication rights granted to the journal.

This is an open-access article distributed under the terms and conditions of the Creative Commons Attribution license (http://creativecommons.org/licenses/by/4.0/). 